\title{
Development of the Experimental Food Book as a Research Guide for Food and Nutrition Student
}

\author{
Esi Emilia ${ }^{1 *}$, Lelly Fridiaty ${ }^{1}$, Yuspa Hanum ${ }^{1}$, Rasita Purba ${ }^{1}$, Risti Rosmiati ${ }^{1}$, Yesica \\ Marcelina Romauli Sinaga ${ }^{1}$ \\ \{*esiemilia@unimed.ac.id, lellyfhsb@gmail.com, yuspa.hanum@gmail.com, rasita_purba@yahoo.com, \\ risti.rosmiati@gmail.com,yesica.sinaga@gmail.com \}
}

Department of Family Welfare Education, Faculty of Engineering, Universitas Negeri Medan, Medan, Indonesia ${ }^{1}$

\begin{abstract}
Product development is an essential activity in the food industry and it is a required competency of food and nutrition student. The objective of the study was to develop the experimental food book as a research guide for food and nutrition student. The study used research and development method with 4D (define, design, develop and dissemination) research model was conducted from May to October 2018 in Medan City. The experimental food book has been designed according to the food and nutrition students need and validated by food and nutrition, educational and media experts. The book consists of the early presentation of necessary information on methods, planning, and evaluation for those who will be doing food experimental. Moreover, how to report the results. The food experimental food could be used as a research guide for food and nutrition student.
\end{abstract}

Keywords: Experimental, food, guidebook, nutrition

\section{Introduction}

Indonesia still faces nutritional problems that have a severe impact on the quality of human resources [1], [2]. In Indonesia, 30.8\% of under-five children suffer from stunting and $10.2 \%$ wasting [3]. Moreover, the prevalence rate of anemia among pregnant women is $48.9 \%$ [3] that can increase risk of significant low birth weight (LBW) delivery [4], [5].

The most common efforts for meeting nutrient requirement of under-five children and pregnant women include dietary diversification and selection of nutrient-rich foods, supplementation with multivitamins and mineral, fortification of staple foods, and use of fortified food product specially designed for this target group [6]-[9]. Many aspects must be considered in developing a new food product. To meet the goals, we need to pay attention to the characteristics of food ingredients, nutrient content, availability of raw materials, processing, sensory characteristics, safety, storage, cost, and acceptability.

Product development is an essential activity in the food industry, and it is a required competency of food and nutrition student. The objective of the study was to develop the experimental food book as a research guide for food and nutrition student. 


\section{Methodology}

The study was conducted from May to October 2018 in Medan City used to research and development method with 4D (define, design, develop and disseminate) research model. Define (needs analysis) aims to collect information in the field for the development of products through initial analysis; the student needs assessment, material analysis, and goal setting. The design process was carried out by interviews with lecturers and literature studies. Furthermore, the development phase aims to produce the final product after going through the process of validation, revision, and pilot test. The design results are validated by nutrition, educational, and media experts. Expert validation results are revised. The dissemination stage is the last stage in the development of the 4D model to promote products.

\section{Result and Discussion}

The experimental food book is a research guide that is expected to be used primarily by food and nutrition students. Moreover, the book was made as an effort to improve nutritional problems by improving the food consumed [6]-[9].

\subsection{Experimental Food Book Material Identification}

Identification of the experimental food book material was carried out by collecting several books and other references related to food experiments. It is called define stage of the 4-D model. Furthermore, the material was arranged based on the stages of food experiments from the introduction to analyzing the data and present the reports. Some similar research used the method as an initial stage of teaching media development [10], [11].

The experimental food book discussed the things needed for designing food with a scientific approach to food problems such as food preparation and storage, nutrient content, and how to develop new food products. The literature review reference of experimental food book present in Table 1. Some journals related to food experiment [12]-[16] were studied to enrich the book literature.

Table 1. The literature review reference of experimental food book

\begin{tabular}{|c|c|c|c|}
\hline No & Title & Author(s)/Editor(s) & Year \\
\hline 1 & $\begin{array}{l}\text { A handbook for Sensory and } \\
\text { Consumer-Driven New Product } \\
\text { Development }\end{array}$ & Maurice G. O’Sullivan & 2017 \\
\hline 2 & $\begin{array}{l}\text { Accelerating New Food Product } \\
\text { Design and Development, } 2^{\text {nd }} \text { Edition }\end{array}$ & $\begin{array}{l}\text { Jacqueline H. Beckley; } \\
\text { Leslie j. Herzog; Michele } \\
\text { Foley }\end{array}$ & 2017 \\
\hline 3 & $\begin{array}{l}\text { An Integrated Approach to New Food } \\
\text { Product Development }\end{array}$ & $\begin{array}{l}\text { Howard R. Moskowitz; I. } \\
\text { Sam Saguy; Tim Straus }\end{array}$ & 2009 \\
\hline 4 & $\begin{array}{l}\text { Descriptive Analysis in Sensory } \\
\text { Evaluation }\end{array}$ & $\begin{array}{l}\text { Sarah E. Kemp; Joanne } \\
\text { Hort; Tracey Hollowood }\end{array}$ & 2018 \\
\hline 5 & $\begin{array}{l}\text { Developing New Functional Food and } \\
\text { Nutraceutical Products }\end{array}$ & $\begin{array}{l}\text { Debasis Bagchi' Sreejayan } \\
\text { Nair }\end{array}$ & 2017 \\
\hline 6 & $\begin{array}{l}\text { Experimental Food Science, } 3^{\text {rd }} \\
\text { Edition }\end{array}$ & $\begin{array}{l}\text { Marjorie P. Penfield; Ada } \\
\text { Marie Campbell }\end{array}$ & 1990 \\
\hline
\end{tabular}




\begin{tabular}{|c|c|c|c|}
\hline 7 & Food Science, $5^{\text {th }}$ Edition & $\begin{array}{l}\text { Norman N. Potter; Joseph } \\
\text { h. Hotchkiss }\end{array}$ & 1995 \\
\hline 8 & $\begin{array}{l}\text { Low Cost, Low-Tech Innovation: } \\
\text { New Product Development in Food }\end{array}$ & Vijay Vyas & 2015 \\
\hline 9 & $\begin{array}{l}\text { New Food Product Development: } \\
\text { From Concept to Marketplace } 3^{\text {rd }} \\
\text { Edition }\end{array}$ & Gordon W. Fuller & 2011 \\
\hline 10 & $\begin{array}{l}\text { Rapid Sensory Profiling Techniques } \\
\text { and Related Methods }\end{array}$ & $\begin{array}{l}\text { Julien Delarue; J. Ben } \\
\text { Lawlor; Miche Rogeaux }\end{array}$ & 2015 \\
\hline 11 & $\begin{array}{l}\text { Sensory Evaluation Techniques, } 5^{\text {th }} \\
\text { Edition }\end{array}$ & $\begin{array}{l}\text { Morten C. Meilgaard; Gail } \\
\text { Vance Civille; B. Thomas } \\
\text { Carr }\end{array}$ & 2016 \\
\hline 12 & $\begin{array}{l}\text { The food chemistry Laboratory: A } \\
\text { Manual for Experimental Foods, } \\
\text { Dietetics and Food Scientists, } 2^{\text {nd }} \\
\text { Edition }\end{array}$ & $\begin{array}{l}\text { Connie M. Weaver; James } \\
\text { R. Daniel }\end{array}$ & 2005 \\
\hline
\end{tabular}

\subsection{Designing the Experimental Food Book}

The next stage after preparing food experiment book material was designing a book from the cover, table of contents, contents of the book and closing. Chapter 1 is an explanation and principles of food experiments and ending with suggestion practice. Chapter 2 and 3 presents information about development a new food product and aspects to be considered related to food science such as the effect of processing on nutrients. Chapter 4 tries to answer the demands due to globalization in the economic field to the development of new products, including generating ideas and realizing them.

Chapter 5 presents product optimization techniques specifically for nutritional parameters and costs both manually and computerized. Chapter 6 and 7 discuss the food evaluation by objective and sensory methods. Food product must have a good quality, attractive flavor and appearance, balanced and safety nutritional content. The last chapter showed how to present the food experimental reports.

The experiment food science has two main objectives, namely to present the scientific basis for understanding the nature of food and to promote the principles of the food experiment methodology. The food experiment studies are concerned with why foods are handled, processed, and prepared as they are, how and why variations in ingredients or treatment influence the food quality, and how this knowledge can be used to improve the food products quality.

\section{Conclusion}

The experimental food book has been designed according to the food and nutrition students need and validated by food and nutrition, educational and media experts. The book consists of the early presentation of necessary information on methods, planning, and evaluation for those who will be doing food experimental. Moreover, how to report the results. The food experimental food could be used as a research guide for food and nutrition student. 


\section{References}

[1] C. P. Stewart, L. Iannotti, K. G. Dewey, K. F. Michaelsen, and A. W. Onyango, "Original Article Contextualising complementary feeding in a broader framework for stunting prevention," vol. 9, pp. 27-45, 2013.

[2] S. Grantham-mcgregor, Y. B. Cheung, S. Cueto, P. Glewwe, L. Richter, and B. Strupp, "Child development in developing countries 1 Developmental potential in the fi rst 5 years for children in," vol. 369, 2007.

[3] M. of H. MOH, "Basic Healt Research 2018," 2018.

[4] L. H. Allen, "Anemia and iron deficiency : effects on pregnancy outcome 1-3," vol. 71, pp. $1280-1284,2000$.

[5] N. M. Abu-Ouf and M. M. Jan, "The impact of maternal iron deficiency and iron deficiency anemia on child's health," Saudi Med J, vol. 36, no. 2, pp. 146-149, 2015.

[6] K. G. Dewey, "Review Article Reducing stunting by improving maternal , infant and young child nutrition in regions such as South Asia : evidence , challenges and opportunities," vol. 12, pp. 27-38, 2016.

[7] S. Kureishy et al., "A mixed methods study to assess the effectiveness of food-based interventions to prevent stunting among children under- five years in Districts Thatta and Sujawal, Sindh Province, Pakistan : study protocol," BMC Public Health, pp. 1-6, 2017.

[8] B. Martinez et al., "Complementary feeding intervention on stunted Guatemalan children : a randomised controlled trial," pp. 1-8, 2018.

[9] V. M. Aguayo and P. Menon, "Introduction Stop stunting: improving child feeding, women ' s nutrition and household sanitation in South Asia," vol. 12, pp. 3-11, 2016.

[10] A. G. Irawan, N. Padmadewi, and L. P. Artini, "Instructional materials development through 4D model "," vol. 00086, pp. 1-4, 2018.

[11] L. Sukariasih, "Development of Integrated Natural Science Teaching Materials Webbed Type with Applying Discourse Analysis on Students Grade VIII in Physics Class Development of Integrated Natural Science Teaching Materials Webbed Type with Applying Discourse Analysis on," J. Phys. Conf. Ser., vol. 846, no. 012028, pp. 1-8, 2017.

[12] A. Tejram, G. Sahay, N. Upadhyay, Y. Khetra, S. Borad, and A. Kumar, "LWT - Food Science and Technology Production and characterization of milk protein concentrates 60 ( MPC60) from bu ff alo milk," vol. 91, no. January, pp. 368-374, 2018.

[13] E. Sheibani and A. Mohammadi, "The impacts of water compositions on sensory properties of foods and beverages cannot be underestimated," vol. 108, no. March, pp. 101-110, 2018.

[14] X. Tang et al., "LWT - Food Science and Technology Impact of in situ formed exopolysaccharides on dough performance and quality of Chinese steamed bread," vol. 96, no. May, pp. 519-525, 2018.

[15] T. Wandersleben et al., "LWT - Food Science and Technology Enhancement of functional and nutritional properties of bread using a mix of natural ingredients from novel varieties of $\mathrm{fl}$ axseed and lupine," vol. 91, no. July 2017, pp. 48-54, 2018.

[16] M. Chalamaiah, Y. Esparza, H. Hong, F. Temelli, and J. Wu, "Physicochemical and functional properties of leftover egg yolk granules after phosvitin extraction," vol. 268, no. May, pp. 369377, 2018. 